\title{
Record of Epibiont ciliates (Ciliophora: Peritrichia) living on larvae of Odonata from Brazil
}

\author{
J. J. Corbi ${ }^{a *}$, D. P. Abrahão ${ }^{a}$, J. L. S. Mello and G. R. Gorni ${ }^{a}$ \\ aLaboratório de Ecologia de Ambientes Aquáticos - LEEA, Departamento de Hidráulica e Saneamento - SHS, \\ Universidade de São Paulo - USP, Avenida Trabalhador Sãocarlense, 400, CEP 13566-590, São Carlos, SP, Brazil \\ *e-mail: julianocorbi@usp.br
}

Received: October 30, 2015 - Accepted: February 17, 2016 - Distributed: May 31, 2017

(With 1 figure)

\begin{abstract}
Historically, epibiosis was understood as a commensalism relation between two or more organisms. However, some studies have shown that epibionts can cause deleterious effects to their host (see Puckett and Carman, 2002). Numerous species of protozoa belonging to the group of peritrich Ciliophora can be found inhabiting other aquatic organisms. Epibiosis is a facultative relationship of two organisms: the epibiont and the basibiont. The word "epibiont" includes organisms that, during the sessile stage of their life cycle, are attached to the surface of a living substratum, while the basibiont lodges and constitutes a support (Fernandez-Leborans and Tato-Porto, 2000; Dias et al. 2007). As pointed out by Wahl (1989), because of epibiosis, the host and the epibiont have beneficial and negative aspects. The negative effects of epibiosis on the host may involve, for example, a decrease in survival capability and perturbation of movement (Henebry and Ridgeway, 1979). Epibiosis is beneficial for epibiont protozoa, which can be transported to regions richer in food or to much more oxygenated places, as pointed out by Regali-Seleghim and Godinho (2004). As pointed by Liu and Gong (2012), peritrichs are a diverse, ecologically important ciliate group usually with a complex life cycle (Liu and Gong, 2012).
\end{abstract}

Several ciliate protozoans live as epibionts on animals and plants, using them as substrate (Dias et al., 2007). Most ciliates, for example, of the genus Rhabdostyla Kent, 1880 (Peritrichia, Epistylidae), live as epibionts of freshwater invertebrates, such as rotifers, crustaceans (Cladocerans, Copepods), insects from the orders Ephemeroptera and Diptera (Chironomidae), and annelids (Oligochaeta and Polychaeta) (Dias et al., 2007). Along these lines, Regali-Seleghim and Godinho (2004) found Rhabdostyla sp. and Scyphidia sp. living on copepods, Fernandez-Leborans and Tato-Porto (2000) points to epibionts living on custraceans, Dias et al. (2007) found Rhabdostyla chironomi inhabiting the Chironomidae larvae ventral tubles, Dias et al. (2009a) that found the occurrence of peritrich ciliates on the limnic oligochaete Limnodrilus hoffmeisteri and Dias et al. (2009b) that points the occurrence of Epistylis sp. (Ciliophora: Peritrichia) living on nymphs of Kempnyia (Plecoptera). Other researchers, such as Primc (1988) pointed that ciliates have a complex network of interacting feeding relationships at various trophic levels and found that in organically enriched aquatic systems, increased concentrations of phosphates and other nutrients alters the abundance of peritrich populations.

Here, we report a first record of epibiont ciliates (Ciliophora: Peritrichia) living on larvae of Coenagrionidae (Odonata) in Brazil (see Figure 1). The organisms were collected in September 2015, from the Monjolinho Reservoir, using a " $D$ " aquatic net, during a survey of benthic macroinvertebrates. This reservoir is located in the campus of the Federal University of São Carlos (São Paulo, Brazil) in a subtropical region $\left(47^{\circ} 53^{\prime} \mathrm{W}\right.$ and $\left.22^{\circ} 01^{\prime} \mathrm{S}\right)$. The Odonata were identified using the special identification key (Hamada et al., 2014; Mugnai et al., 2010). We recorded the occurrence of epibiont ciliates (Protozoa: Ciliophora) living on larvae of Coenagrionidae (Odonata). The epibiont ciliates were found attached to some body part of the Odonata larvae, but most usually located on the head and on the pronotum and mesonotum (thorax) (see Figure 1). The presence of epibionts mostly on the head and on the pronotum and mesonotum (thorax) of the Odonata can bring some feed difficulties for these predator aquatic organism. On the other hand, as pointed by Henebry and Ridgeway (1979) since peritrichs primarily consume bacteria, their location on the body of the host is indifferent. However, adhesion to appendages is probably inadequate because epibionts may be lost with the attrition caused by movements and, according to Green (1974), the frequent perturbation by the antenna of the host interrupts the feeding of peritrichs, causing zooid contraction. On the other hand, Regali-Seleghim and Godinho (2004) consider that bigger organisms are easier targets for the epibionts than smaller ones. Consequently, our observations may be related to epibiont preference for these aquatic organisms or to the presence of a comparatively larger adhesion surface offered by each Odonata individual. 


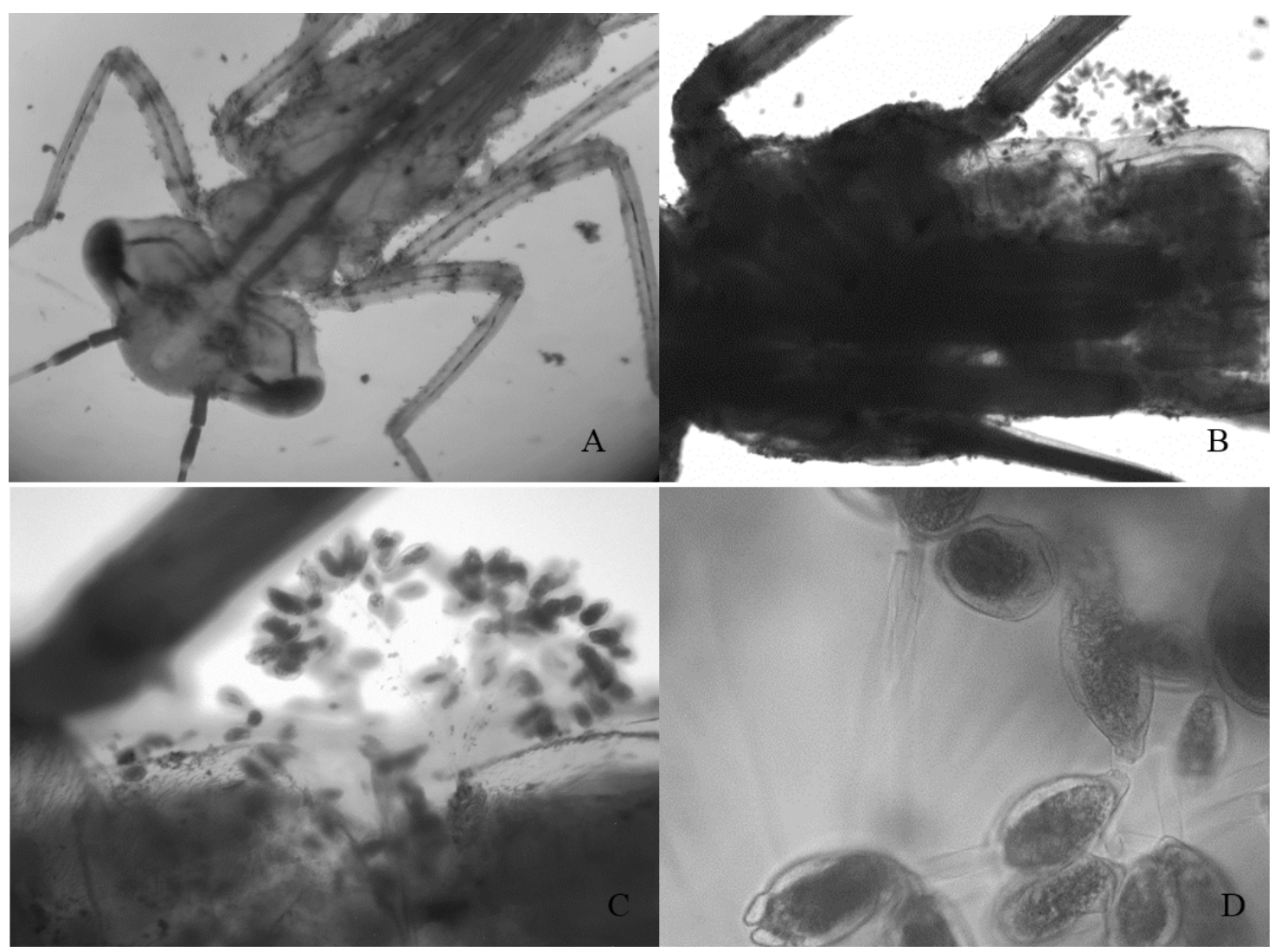

Figure 1. (A) Coenagrionidae (Odonata) with Epibiont ciliates (Protozoa: Ciliophora); (B) Zoom in Epibiont ciliates (Ciliophora:Peritrichia) on the dorsal side (thorax) of Coenagrionidae (Odonata) (zoom 4×); (C) Epibiont ciliates (Ciliophora:Peritrichia) (zoom 10×); (D) Epibiont ciliates (Ciliophora:Peritrichia) (zoom 40×).

\section{Acknowledgements}

We would like to thank Professor Vanessa Colombo-Corbi for their fruitful suggestions. Financial support: FAPESP, process number 2013/24268-2.

\section{References}

DIAS, R.J.P., CABRAL, A.F., STEPHAN, N.N.C., MARTINS, R.T., SILVA-NETO, I.D., ALVES, R.G. and D'AGOSTO, M., 2007. Record of Rhabdostyla chironomi Kahl, 1933 (Ciliophora, Peritrichia) Epibiont on Chironomidae larvae (Diptera, Chironomidae) in a lotic system in Brazil. Brazilian Journal of Biology = Revista Brasileira de Biologia, vol. 67, no. 4, pp. 783-785. http://dx.doi.org/10.1590/S1519-69842007000400030. PMid:18278337.

DIAS, R.J.P., CABRAL, A.F., MARTINS, R.T., STEPHAN, N.N.C., SILVA-NETO, I.D., ALVES, R.G. and D'AGOSTO, M., 2009a. Occurrence of peritrich ciliates on the limnic oligochaete Limnodrilus hoffmeisteri (Oligochaeta, Tubificidae) in the neotropics. Journal of Natural History, vol. 43, no. 1-2, pp. 1-15. http://dx.doi.org/10.1080/00222930802478644.

DIAS, R.J.P., SILVA-NETO, I.D. and COSTA, J.M., 2009b. Sítio de localização de protistas ciliados peritríquios (Ciliophora: Peritrichia) epibiontes sobre ninfas de Kempnyia Klapálek, 1914
(Insecta: Plecoptera: Perlidae). In: Anais do $9^{\circ}$ Congresso de Ecologia do Brasil, 13-17 Setembro 2009, São Lourenço, Brasil. São Lourenço: Sociedade de Ecologia do Brasil, vol. 9, pp. 1-3.

FERNANDEZ-LEBORANS, R. and TATO-PORTO, M.L., 2000. Review of the species of protozoan epibionts on crustaceans. I. Peritrich ciliates. Crustaceana, vol. 73, no. 6, pp. 643-683. http://dx.doi.org/10.1163/156854000504705.

GREEN, J., 1974. Parasites and epibionts of Cladocera. Transactions of the Zoological Society of London, vol. 32, no. 6, pp. 417-515. http://dx.doi.org/10.1111/j.1096-3642.1974.tb00031.x.

HAMADA, N., NESSIMIAN, J.L. and RANYE-BARBOSA, Q., 2014. Insetos aquáticos da Amazônia brasileira: taxonomia, biologia e ecologia. Manaus: Editora do INPA, 724 p.

HENEBRY, M.S. and RIDGEWAY, B.T., 1979. Epizoic ciliated protozoa of planktonic Copepods and Cladocerans and their possible use as indicators of organic pollution. Transactions of the American Microscopical Society, vol. 98, no. 4, pp. 495-508. http://dx.doi.org/10.2307/3225899.

LIU, X. and GONG, J., 2012. Revealing the diversity and quantity of peritrich ciliates in environmental samples using specific primer-based PCR and quantitative PCR. Microbes and Environments, vol. 27, no. 4, pp. 497-503. http://dx.doi. org/10.1264/jsme2.ME12056. PMid:23100023. 
MUGNAI, R., NESSIMIAN, J.L. and BAPTISTA, D.F., 2010. Manual de identificação de macroinvertebrados aquáticos do Estado do Rio de Janeiro. 1. ed. Rio de Janeiro: Technical Books. 176 p.

PRIMC, B., 1988. Trophic relationships of ciliated Protozoa developed under different saprobic conditions in the periphyton of the Sava River. Periodicum Biologorum, vol. 90, pp. 349-353.

PUCKETT, G.L. and CARMAN, K.R., 2002. Ciliate epibiont effects on feeding, energy reserves, and sensitivity to hydrocarbon contaminants in an estuarine harpacticoid copepod. Estuaries, vol. 25, no. 3, pp. 372-381. http://dx.doi.org/10.1007/BF02695980.

REGALI-SELEGHIM, M.G. and GODINHO, M.J.L., 2004. Peritrich epibiont protozoans in the zooplankton of a subtropical shallow aquatic ecosystem (Monjolinho Reservoir, São Carlos, Brazil). Journal of Plankton Research, vol. 26, no. 5, pp. 501508. http://dx.doi.org/10.1093/plankt/fbh055.

WAHL, M., 1989. Marine epibiosis. 1. Fouling and antifouling: some basic aspects. Marine Ecology Progress Series, vol. 58, pp. 175-189. http://dx.doi.org/10.3354/meps058175. 